\title{
Effects of Wastewater Effluent Discharge on Stream Quality in Indian Creek, Johnson County, Kansas
}

\section{By Jennifer L. Graham and Guy M. Foster}

\section{Abstract}

Contaminants from point and other urban sources affect stream quality in Indian Creek, which is one of the most urban drainage basins in Johnson County, Kansas. The Johnson County Douglas L. Smith Middle Basin and Tomahawk Creek Wastewater Treatment Facilities discharge to Indian Creek. Data collected by the U.S. Geological Survey, in cooperation with Johnson County Wastewater, during June 2004 through June 2013 were used to evaluate stream quality in Indian Creek. This fact sheet summarizes the effects of wastewater effluent discharge on physical, chemical, and biological conditions in Indian Creek downstream from the Douglas L. Smith Middle Basin and Tomahawk Creek Wastewater Treatment Facilities.

\section{Introduction}

Contaminants from point and other urban sources affect stream quality in Indian Creek, which is one of the most urban drainage basins in Johnson County, Kansas. The Johnson County Douglas L. Smith Middle Basin (hereafter referred to as "Middle Basin") and Tomahawk Creek Wastewater Treatment Facilities (WWTFs) discharge to Indian Creek (fig. 1). In summer 2010, upgrades to increase capacity from 18.6 to 22.4 cubic feet per second and include biological nutrient removal at the Middle Basin WWTF were completed. There were no infrastructure changes at the Tomahawk Creek WWTF; however, during 2009, chemically enhanced primary treatment was added to the treatment process for better process settling before disinfection and discharge with the added effect of enhanced phosphorus removal. Data collected by the U.S. Geological Survey, in cooperation with Johnson County Wastewater, during June 2004 through June 2013 were used to evaluate stream quality in Indian Creek (Graham and others, 2014; Stone and Graham, 2014). Indian Creek study findings provide insight into the effects of

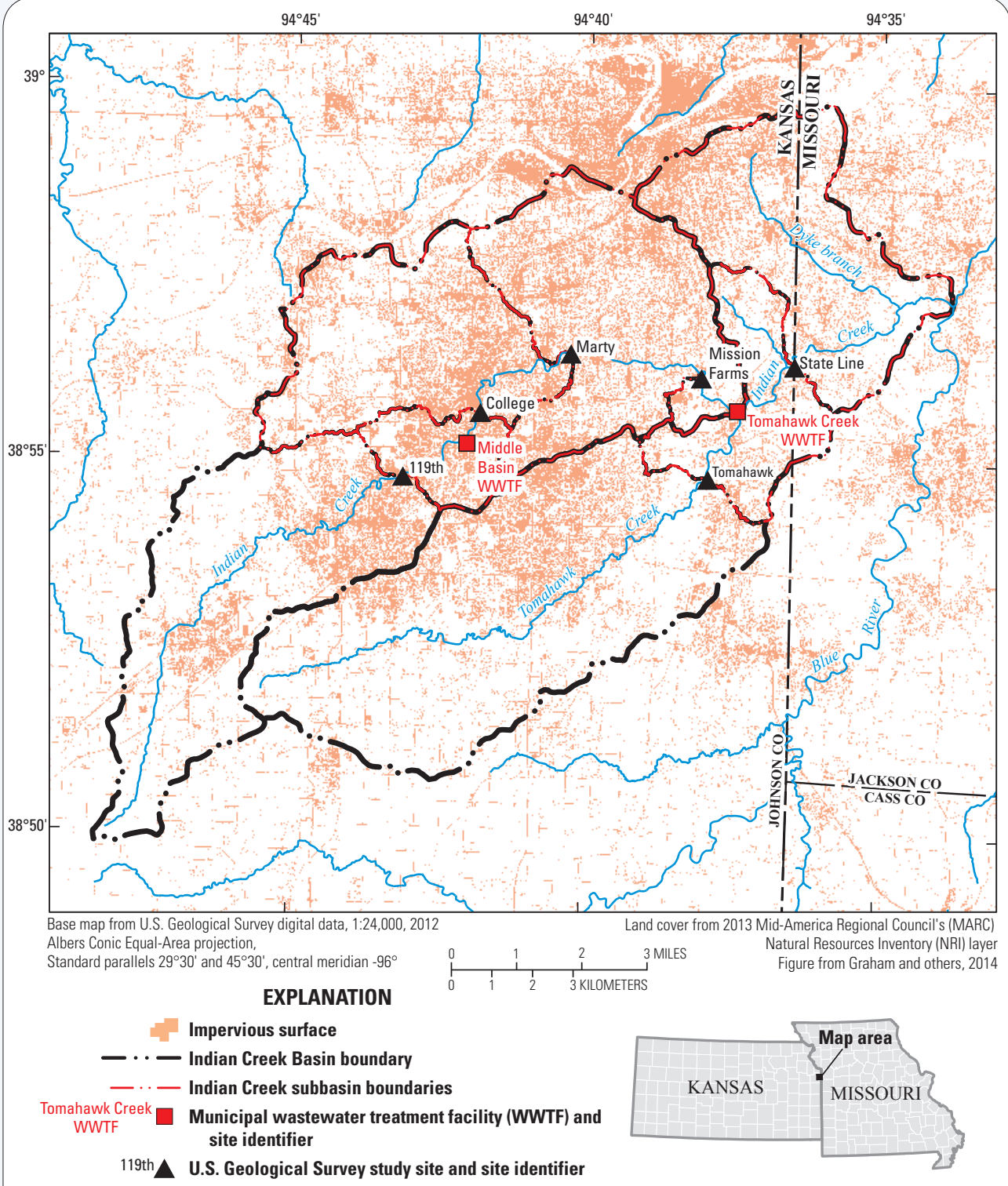

Figure 1. Location of municipal wastewater treatment facilities and study sites in the Indian Creek drainage basin. wastewater effluent on stream-water and streambed sediment quality, biological community composition, and ecosystem function in urban areas. Detailed results from the Indian Creek study are presented in Graham and others (2014).

\section{Approach}

The effects of wastewater effluent on physical, chemical, and biological conditions in Indian Creek were assessed by comparing two urban upstream sites to four urban sites located 
downstream from the WWTFs (fig. 1). Five sites were located on Indian Creek and one was located on Tomahawk Creek, the largest tributary to Indian Creek. Physical and chemical conditions were evaluated using previously (June 2004-May 2011) and newly (June 2011June 2013) collected discrete and continuous data, and were compared with an assessment of biological community composition and ecosystem function along the upstream-downstream gradient.

\section{Wastewater Effluent Nutrient Concentrations and Loads}

After the addition of biological nutrient removal to the Middle Basin WWTF (fig. 1) in 2010, annual mean total nitrogen concentrations in effluent decreased by 46 percent, but still exceeded the National Pollutant Discharge Elimination System (NPDES) wastewater effluent permit concentration goal of 8.0 milligrams per liter $(\mathrm{mg} / \mathrm{L})$. The NPDES wastewater effluent permit total phosphorus concentration goal of $1.5 \mathrm{mg} / \mathrm{L}$ or less was achieved in 2010, 2012, and 2013 at the Middle Basin WWTF after the addition of biological nutrient removal in 2010 (fig. $2 A$ ). At the Tomahawk Creek WWTF (fig. 1), after the addition of chemically enhanced primary treatment in 2009, effluent discharges also had concentrations below $1.5 \mathrm{mg} / \mathrm{L}$ (fig. $2 B$ ).

\section{After changes in treatment practices, nutrient loads} from the WWTFs decreased by $40-55$ percent.

After the addition of biological nutrient removal, annual total nitrogen and phosphorus loads from the Middle Basin WWTF decreased by 42 and 54 percent, respectively, even though effluent volume increased by 11 percent (fig. $2 C$ ). Annual total phosphorus loads from the Tomahawk Creek WWTF after the addition of chemically enhanced primary treatment decreased by 54 percent despite a 33 percent increase in effluent volume (fig. 2D). Total nitrogen and phosphorus (figs. $3 A$ and $3 B$, respectively) from the WWTFs contributed between about 30 and nearly 100 percent to annual nutrient loads in Indian Creek depending on streamflow conditions. In-stream total nitrogen load primarily came from wastewater effluent except during years with the highest streamflows (2010; fig. $3 A$ ). Most of the in-stream total phosphorus load typically came from effluent during dry years (2006) and from other urban sources during wet years (2010; fig. 3B).

During 2010 through 2013, annual mean discharge from the Middle Basin WWTF was about 75 percent of permitted design capacity. Annual nutrient loads likely will increase when the facility is operated at permitted design capacity; however, estimated maximum annual nutrient loads from the Middle Basin WWTF were 27 to 38 percent lower than before capacity upgrades and the addition of biological nutrient removal to treatment processes (fig. $2 C$ ). Thus, the addition of biological nutrient removal to the Middle Basin wastewater treatment process should reduce overall nutrient loads from the facility even when the facility is operated at permitted design capacity (figs. $2 A$ and $2 C$ ).

\section{Stream Quality in Indian Creek}

The effects of wastewater effluent on the water quality of Indian Creek (fig. 1) were most evident during below-normal and normal streamflows (about 75 percent of the time) when 

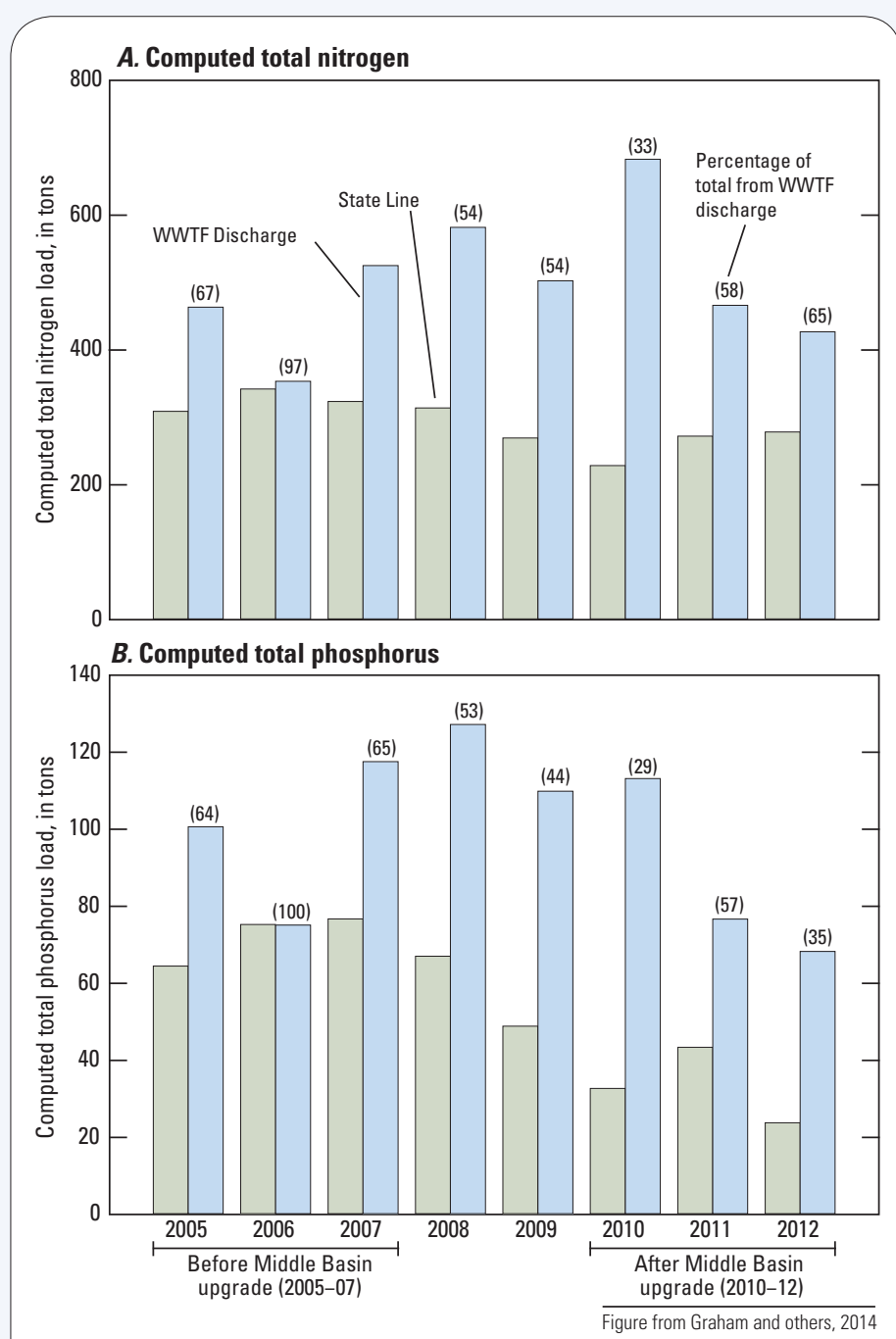

Figure 3. Computed total nutrient loads originating from wastewater treatment facility (WWTF) discharges compared to total loads at the State Line site during 2005 through 2012. $A$, computed total nitrogen and $B$, computed total phosphorus.

wastewater effluent represented about 24 percent or more of total streamflow. Wastewater effluent had the most substantial effect on nutrient concentrations in Indian Creek. Total and inorganic nutrient concentrations at the downstream sites during below-normal and normal streamflows were 10 to 100 times higher than at the upstream sites even after changes in treatment practices at the WWTFs. For example, based on continuously measured data, median nitrate plus nitrite concentrations at the downstream sites were 10 to 15 times higher than at the upstream sites during April 2012 through June 2013.

Wastewater effluent had a substantial effect on nutrient concentrations in Indian Creek.

In addition, the Kansas Department of Health and Environment (KDHE) nitrate total maximum daily load value of $10 \mathrm{mg} / \mathrm{L}$ for Indian Creek (Kansas Department of Health and Environment, 2007) was only exceeded at the sites immediately downstream from the WWTFs (fig. 4). Total phosphorus concentrations during below-normal and normal streamflows at the downstream State Line site decreased by 42 percent following improvements

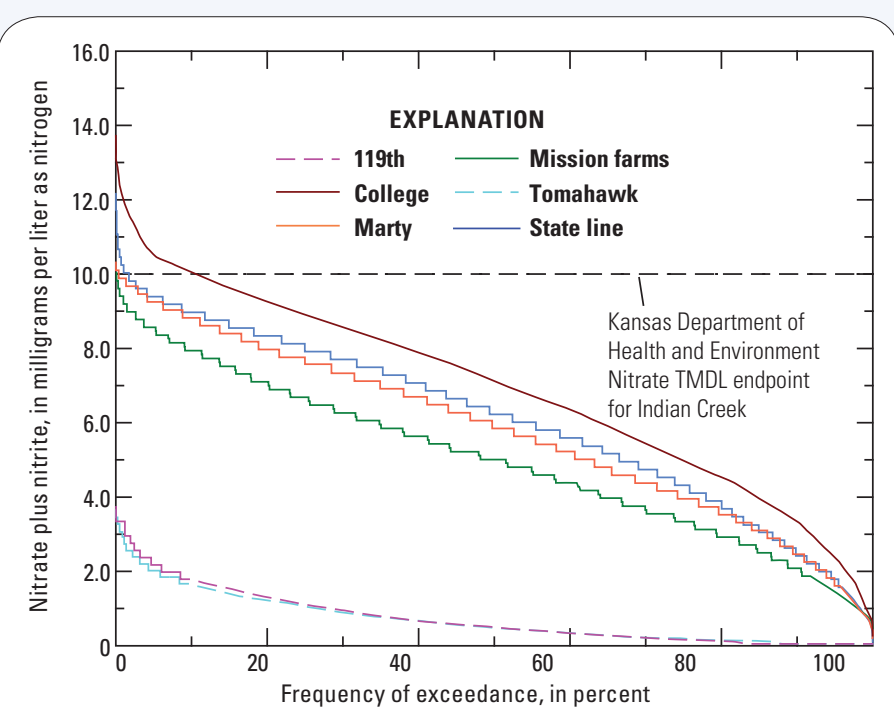

$\overline{\text { Figure from Graham and others, } 2014}$

Figure 4. Duration curves for continuously measured nitrate plus nitrite at all Indian Creek study sites, April 2012 through June 2013.

in wastewater treatment processes. Similar decreases in total nitrogen were not observed likely because total nitrogen concentrations only decreased in Middle Basin effluent, and wastewater contributed a higher percentage to streamflows when nutrient samples were collected during the after-upgrade period.

Other urban sources of contaminants also caused changes in stream-water quality, including higher turbidities downstream from construction areas, and higher specific conductance and chloride concentrations during winter months. Chloride concentrations exceeded U.S. Environmental Protection Agency (1988) acute $(230 \mathrm{mg} / \mathrm{L})$ and chronic $(860 \mathrm{mg} / \mathrm{L})$ exposure criteria for protection of aquatic life at all Indian Creek study sites, regardless of wastewater influence, for weeks or months during winter. Streambed sediment chemistry was affected by wastewater (elevated nutrient and organic wastewater-indicator compound concentrations) and other contaminants from urban sources (elevated polyaromatic hydrocarbon [PAH] concentrations). Overall habitat conditions were suboptimal or marginal at all study sites; general decline in habitat conditions along the upstream-downstream gradient likely was caused by the cumulative effects of urbanization with increasing watershed size.

Other urban sources of pollutants also caused changes in Indian Creek stream quality.

The relative abundance of algae indicative of nutrient enrichment increased immediately downstream from the WWTFs and generally decreased thereafter as distance from WWTF effluent discharge increased. Macroinvertebrate communities indicated impairment at all sites, and KDHE aquatic life support scores indicated conditions nonsupporting of aquatic life (Kansas Department of Health and Environment, 2008), regardless of wastewater influences (fig. 5). Urban influences, other than wastewater effluent discharge, likely structure macroinvertebrate communities in Indian Creek. 


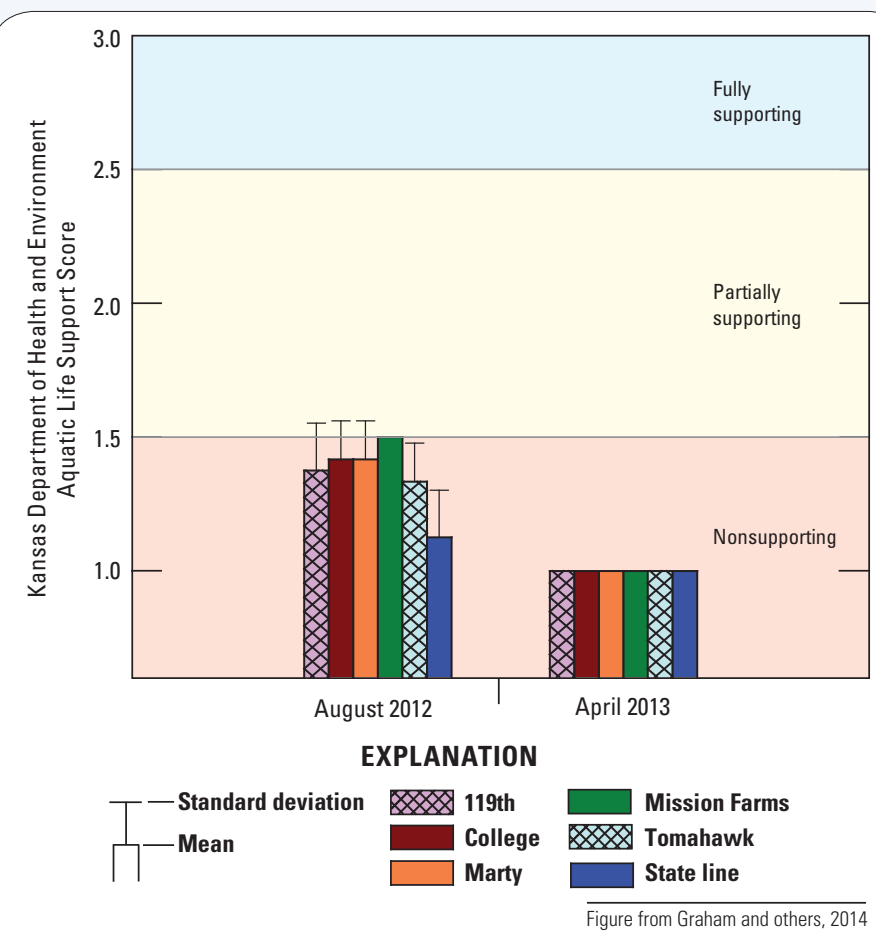

Figure 5. Kansas Department of Health and Environment Aquatic Life Support Scores at all Indian Creek study sites during August 2012 and April 2013.

Wastewater effluent discharge into Indian Creek likely contributed to changes in measures of ecosystem structure (streamflow, water and streambed-sediment chemistry, algal biomass, and algal periphyton community composition) and

Urban influences likely structure macroinvertebrate communities in Indian Creek.

function (primary production and community respiration) along the upstream-downstream gradient. As distance from the Middle Basin WWTF (fig. 1) increased, nutrient concentrations, algal biomass, primary production, and community respiration decreased. By the Mission Farms site, located 9.5 kilometers downstream from the discharge, functional stream health was no longer impaired relative to the urban upstream 119th site without wastewater influence.

\section{Summary}

The U.S. Geological Survey, in cooperation with Johnson County Wastewater, assessed the effects of wastewater effluent discharge on stream quality in Indian Creek, Johnson County, Kansas. Indian Creek study findings provide insight into the effects of wastewater effluent on stream-water and streambed sediment quality, biological community composition, and ecosystem function in urban areas. Detailed results from the Indian Creek study are presented in Graham and others (2014).

Several environmental conditions at all Indian Creek study sites were associated with urbanization, including degraded habitat conditions, elevated chloride concentrations, and polyaromatic hydrocarbons (PAHs) in streambed sediment. Urban influences, rather than wastewater effluent discharges alone, likely affect biological conditions, particularly macroinvertebrate communities, in Indian Creek. Changes in treatment processes at the Douglas L. Smith Middle Basin and Tomahawk Creek Wastewater Treatment Facilities (WWTFs) improved wastewater effluent quality and decreased nutrient loads, but wastewater effluent discharges still had negative effects on stream quality at downstream Indian Creek sites. Wastewater effluent discharges maintained streamflows and increased nutrient concentrations, algal biomass, primary production, and community respiration at the downstream sites. Although wastewater effluent caused persistent changes in physical, chemical, and biological conditions at sites located immediately downstream from WWTF effluent discharges, some recovery to conditions more similar to the urban upstream 119th site without wastewater influence occurred within a relatively short distance.

\section{References Cited}

Graham, J.L., Stone, M.L., Rasmussen, T.J., Foster, G.M., Poulton, B.C., Paxson, C.P., and Harris, T.D., 2014, Effects of wastewater treatment facility upgrades on environmental and biological conditions of Indian Creek, Johnson County, Kansas, June 2004 through June 2013: U.S. Geological Survey Scientific Investigations Report 2014-5187, 78 p.

Kansas Department of Health and Environment, 2007, Missouri Basin total maximum daily load, waterbody-Indian Creek, water quality impairment-Nitrate: accessed March 2014 at http://www.kdheks.gov/tmdl/mo/IndianCr_Nitrate_2007.pdf.

Kansas Department of Health and Environment, 2008, Kansas integrated water quality assessment: accessed April 2013 at http://www.kdheks.gov/befs/ download/2008IR_040108FINAL.pdf.

Stone, M.L., and Graham, J.L., 2014, Model documentation for relations between continuous real-time and discrete waterquality constituents in Indian Creek, Johnson County, Kansas, June 2004-May 2013: U.S. Geological Survey Open-File Report 2014-1170, 70 p.

U.S. Environmental Protection Agency, 1988, Ambient water quality criteria for chloride-1988: Washington D.C., Office of Water, Regulations and Standards Criteria and Standards Division, 20460.

For additional information concerning this publication, contact: Director, USGS Kansas Water Science Center 4821 Quail Crest Place

Lawrence, KS 66049

(785) 842-9909

Or visit the Kansas Water Science Center Web site at: http://ks.water.usgs.gov

ISSN 2327-6932 (online) http://dx.doi.org/10.3133/fs20143100 